\title{
The morphological diversity of Chrysanthemum resulted from gamma ray irradiation
}

\author{
EMI SUSILA ${ }^{1, \vee}$, ARI SUSILOWATI ${ }^{2}$, AHMAD YUNUS ${ }^{3, \vee v}$ \\ ${ }^{1}$ Bioscience Graduate Program, Universitas Sebelas Maret Jl. Ir. Sutami 36A, Surakarta 57126, Central Java, Indonesia, Tel./fax. +62-271-663375, \\ "email: emisusila08@gmail.com \\ ${ }^{2}$ Department of Biology, Faculty of Mathematics and Natural Sciences, Universitas Sebelas Maret. Jl. Ir. Sutami 36 A, Surakarta 57126, Central Java, \\ Indonesia. \\ ${ }^{3}$ Department of Agrotechnology Faculty of Agriculture, Universitas Sebelas Maret. Jl. Ir. Sutami 36 A, Surakarta 57126, Central Java, Indonesia, \\ Tel./fax.+62-271-637457, "`email: yunusuns17@gmail.com
}

Manuscript received: 16 October 2018. Revision accepted: 26 January 2019.

\begin{abstract}
Susila E, Susilowati A, Yunus A. 2019. The morphological diversity of Chrysanthemum resulted from gamma ray irradiation. Biodiversitas 20: 463-467. Chrysanthemum is a popular ornamental plant. The high market demand makes breeders develop new cultivars to meet market preferences. One way to get superior varieties of Chrysanthemum is by using gamma ray mutation induction which will increase the morphological variations. The purpose of this study is to determine the Chrysanthemum's morphological diversity resulted from gamma irradiation through morphological markers. This experimental research used a completely randomized design (CRD) with one factor, i.e. radiation doses: 0 Gy (control), $10 \mathrm{~Gy}, 15 \mathrm{~Gy}$, and $20 \mathrm{~Gy}$. The observations were carried out qualitatively and quantitatively. The data obtained were analyzed using the SPSS 15.0 and the NTSYS (Numerical Taxonomy and Multivariate Analysis System) 2.02 program. The results showed that increasing the dose of gamma irradiation inhibited plant growth. Irradiation at $10 \mathrm{~Gy}$ and $20 \mathrm{~Gy}$ produced the most color changes in flowers compared to other doses. The basic color of 0 Gy irradiation is purple. Irradiation at $10 \mathrm{~Gy}$ and $20 \mathrm{~Gy}$ produced dark purple and deep red. Quantitative data showed that the treatment of gamma ray irradiation significantly affected the leaf length, leaf width, stem diameter, stem length, and diameter of flowers. The irradiation also caused changes in shape and texture of the leaves. The dendrogram showed that 20 Gy irradiation resulted the most diverse morphology compared to the control, 10 Gy and 15 Gy.
\end{abstract}

Keyword: Chrysanthemum, diversity, gamma irradiation, morphological markers.

\section{INTRODUCTION}

Chrysanthemum (Chrysanthemum) is an ornamental plant that is very popular throughout the world. The shape of the crown, beautiful colors and reasonably priced prices make it dominate most of the flower industries in Southeast Asia and European countries. The high market demand requires breeders to produce new types according to market preferences. In an effort to accelerate the acquisition of new superior varieties of Chrysanthemums that are more diverse, it is necessary to implement more effective breeding techniques using mutation induction (Banerji and Datta, 2002).

One of the mutation inductions used to increase plant diversity is by gamma irradiation as in soybean plants (Mudibu et al. 2012). Gamma rays produce ionizing irradiation that is capable of ionizing materials it goes through. If ionization occurs on or near the chromosome, it will break the chemical bonds and cause changes in the cell nucleus, including the structure of genes, gene or DNA sequence deletions, centromere fractures, chromosome loss or addition, spindle thread damage and so on. These molecular damages cause diversity in irradiated plants, but in certain circumstances, these damages can be repaired during the plant life cycle. This is referred to as physiological damages (Van Harten, 1998).
Morphological markers can be used as a quick way to identify differences between a mutant plant compared to its wild species. The more morphological differences between mutant plants and their wild species, the more changes occur due to gamma ray irradiation. Morphological markers have been widely used to identify changes in several plants, including hazelnuts (Ferreira et al. 2010), long beans (Tantasawat et al. 2010), rice (Oryza sativa) (Yadav et al. 2008).

Plant diversity may be increased through gamma irradiation, but require different irradiation doses for different plants. Datta (2001) reported that the range of gamma ray irradiation on rooted Chrysanthemum cuttings was $10-30 \mathrm{~Gy}$.

This study aims to determine the morphological diversity of Chrysanthemums resulted from gamma ray irradiation based on morphological markers.

\section{MATERIALS AND METHODS}

\section{Time and place}

This research was conducted in November 2017-May 2018. The administration of irradiation was carried out at the Isotope and Irradiation Technology Application Center, National Nuclear Energy Agency (PATIR-BATAN) Pasar 
Jumat, Jakarta, Indonesia and planting was carried out in the Chrysanthemum breeding place in Berjo Village, Ngargoyoso Sub-district, Karanganyar District, Central Java, Indonesia.

\section{Procedures}

Preparation of cuttings seeds

The 2-3 leafed Chrysanthemum cuttings with a maximum height of $6 \mathrm{~cm}$ were cleaned from soil, then the roots were wrapped in aluminum foil.

\section{Gamma ray irradiation}

Cuttings were irradiated using 4000A Gamma Chamber with treatment of $0 \mathrm{~Gy}$ (control), $10 \mathrm{~Gy}, 15 \mathrm{~Gy}$, and $20 \mathrm{~Gy}$.

\section{Planting}

Chrysanthemum cuttings were planted in $30 \mathrm{~cm}$ high planting beds with a spacing of $12 \mathrm{~cm}$ between each cutting. Planting beds were made of mixture of soil with manure $3 \mathrm{~kg} / \mathrm{m}^{2}$, and some basic fertilizers, i.e., $20 \mathrm{~g}$ urea/m2, $30 \mathrm{~g} \mathrm{sp}-36 / \mathrm{m}^{2}$, and $35 \mathrm{~g} \mathrm{KCL} / \mathrm{m}^{2}$.

\section{Maintenance}

The addition of light was done by installing a 23 watts Tube Light lamp for 4 hours at night starting from 22.00 pm - 02.00 am since the beginning of planting for 4 weeks. Watering was carried out in the morning or evening, weeding, NPK every 2 weeks and Gandasil fertilizer in the 3rd week after planting then every 10 days afterward. When the generative stage started after 10 weeks, fertilization was done every 2 weeks using $\mathrm{KNO}_{3}$ fertilizer. Removal of the growing point and the first flower buds was done 3 weeks after planting. Pest control was done using decisive insecticides, and fungi were controlled by Dithine M-45 by dissolving it in water and spraying it on the media.

\section{Observation}

Observations were conducted at 12 weeks after planting. Qualitative observations were made on leaves, stems and flowers, while quantitative observations were carried out by measuring plant height, number of leaves, leaf length, leaf width, stem diameter, flower diameter and number of flowers.

\section{Data analysis}

Qualitative data was described descriptively and quantitative data were calculated using SPSS 15.0 to produce the coefficient of regression. The results of the observations were converted into binary data by scoring data based on the criteria that have been set on each variable. If there was a value on the criterion it was scored as " 1 " and if there was no value then it was scored as "0". The similarity matrix between the mutants was calculated using the Dice algorithm, and the dendrogram analysis was run using the NTSYS (Numerical Taxonomy and Multivariate Analysis System) 2.02 program. (Rohlf, 2000).

\section{RESULTS AND DISCUSSION}

Out of the 40 experimental plants, 25 Chrysanthemums flowered, seven of which were control. This number of flowered plants decreased in the following week of observation due to the death of some plants caused by necrosis and leaf loss. The slowly death of these plants was possibly due to physiological disorders. Herison et al. (2008) stated that the occurrence of abnormalities in irradiated populations indicated changes in genomes, chromosomes, and DNA or genes that were so large that the genetically controlled physiological processes in plants became abnormal and caused genetic variations. Abnormalities and death of irradiated plants were caused by the formation of free radicals such as $\mathrm{H}^{\mathrm{o}}$, which were highly unstable ions in the reaction process due to irradiation. This resulted in many collisions in various directions and consequently would cause changes or mutations in the cell's DNA, tissues, organs, and even death of the plants.

\section{Leaf}

The shape of Chrysanthemum leaf was oval, becoming elongated after being irradiated with 20 Gy light. Changes in leaf shape were due to physiological changes that caused the plants stressed.

There were no differences on the leaf base, tip, color, veination and surface of control and irradiated plants. Leaves of irradiated plants at $10 \mathrm{~Gy}, 15 \mathrm{~Gy}$ and $20 \mathrm{~Gy}$ treatments were generally smaller in size and thicker in texture (Figure 1). Gamma ray irradiation would ionize atoms in plant tissue and produced free radicals $\mathrm{OH}^{\circ}$ and $\mathrm{H}^{\circ}$ and would produce hydrogen peroxide $\left(\mathrm{H}_{2} \mathrm{O}_{2}\right)$ when met with oxygen, so that the amount of $\mathrm{H}_{2} \mathrm{O}_{2}$ in plants increased. $\mathrm{H}_{2} \mathrm{O}_{2}$ is proven to cause damages on cell wall, cell membranes and DNA. Damages to the cell wall and cell membrane due to $\mathrm{H}_{2} \mathrm{O}_{2}$ might cause the Chrysanthemum's leaf texture to become thick and stiff. Wi et al. (2007) showed that $\mathrm{H}_{2} \mathrm{O}_{2}$ accumulation was found in the plasma membrane and in the middle lamella of various plant organs, but most importantly in the leaves. The study of Muthusamy et al. (2007) on peanuts explained that leaf shape variation was increasing along with increasing doses of gamma ray irradiation.

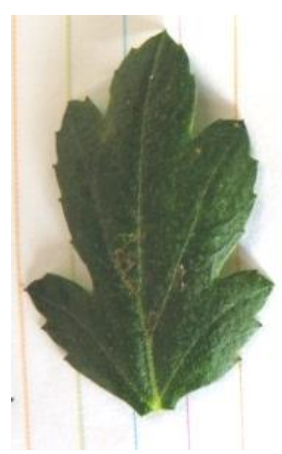

A

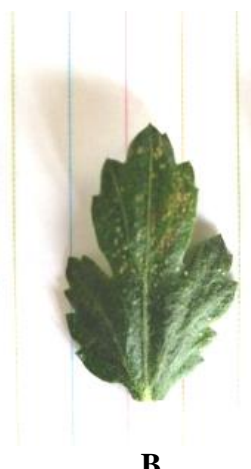

B

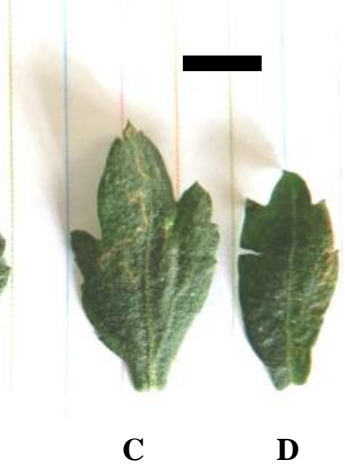

D
Figure 1. Shape of the Chrysanthemum leaves on: A. 0 Gy, B. 10 Gy, C. 15 Gy, D. 20 Gy. Bar $=2 \mathrm{~cm}$ 


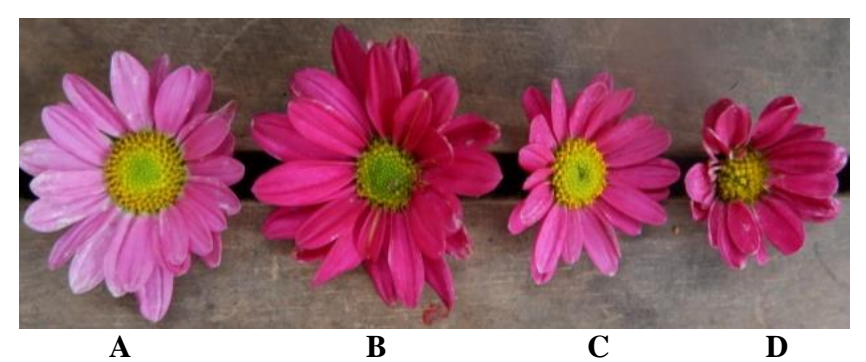

Figure 2. Shape of Chrysanthemum flower on: A. 0 Gy, B. 10 Gy, C. 15 Gy, D. 20 Gy

\section{Flower}

Figure 2 showed that there has been a change in the color of the Chrysanthemum resulting from gamma ray irradiation in the treatment of $10 \mathrm{~Gy}$ and $20 \mathrm{~Gy}$. The flower color of the control was light purple color, while the flower color of treatment $10 \mathrm{~Gy}$ was dark purple and of treatment 20 Gy was dark red.

Gamma ray irradiation caused changes in the color of flowers from light purple to dark purple and dark red. Mutations in flower color are more common in plants treated with $20 \mathrm{~Gy}$. Changes in the flower color were due to radiation because mutations occurred in somatic cells and can be expressed if they occur in the initials of apical cells and would form a stable sector. In addition, expression of mutation was also determined by the position of flower, so that changes would be seen in the flower formed from the mutated tissue (Hartmann et al. 2011). The color of flower was due to the mutation of the gene of controlling flower color.

The results of the variance analysis showed that the dose of gamma irradiation had a significant effect on plant height, leaf length, leaf width, stem diameter and flower diameter. Observation values were generally smaller with increasing doses of gamma ray irradiation (Table 1).

In terms of plant height, the control treatment produced the tallest plants at $52.7 \mathrm{~cm}$, compared to other treatments (Table 1). All treatments were significantly different from controls. The shortest plant was that of the $20 \mathrm{~Gy}$ treatment, i.e., $17.6 \mathrm{~cm}$ (reduced by $66.7 \%$ ). Treatments of $10 \mathrm{~Gy}$ and $15 \mathrm{~Gy}$ each produced a reduction of $33.6 \%$ and $44.6 \%$ respectively. The higher dose of gamma ray irradiation, the shorter the Chrysanthemum plant was. Top shoot meristem cells from plants that were irradiated with high doses were thought to be damaged. The results of this study are in line with that of Srivasta and Kumar (2011) where the higher the dose of gamma irradiation given by safflower plants was shorter when compared to control plants, because gamma irradiation caused interference with DNA synthesis. Ramesh et al. (2014) stated that gamma ray irradiation on mulberry plants caused inhibition of auxin synthesis and cell division.

The highest average number of leaves was 31 leaves in the control, while 20 Gy produced the lowest number of leaves at 29.9. The results of gamma ray irradiation were not significantly different in all treatments. Gamma rays with a 10 Gy treatment resulted in a decrease in the number of leaves by $14.6 \%$ when compared to the control. While for the treatment of $15 \mathrm{~Gy}$ and $20 \mathrm{~Gy}$ each decreased the number of leaves by $2.6 \%$ and $5.2 \%$. Plants that were treated with gamma irradiation had a small number of leaves compared to control treatment plants. This result was in line with the research of Lukanda et al. (2013) on peanuts, where the greater the irradiation dose is given to peanuts resulted in decreasing number of leaves. Decreased number of leaves can be caused by $\mathrm{H}_{2} \mathrm{O}$ and $\mathrm{OH}$ - free radicals. If the hydroxyl radical attaches to the nucleotide chain in DNA, then the single and double strands of DNA will be broken, so that it will cause changes in genes, and the metabolic processes regulated by these genes will automatically change.

The control treatment produced the largest leaf length and width compared to other treatments. The results of the study by Widiastuti et al. (2010) stated that the higher the dose treatment of gamma ray irradiation, the longer and wider the leaf decreases, this can be caused by irradiation and chemical mutagen treatment.

The diameter of the Chrysanthemum stem was significantly different between the control and the treatment of gamma ray Irradiation. The biggest stem diameter was found in the control treatment, which was 3.7 $\mathrm{mm}$ while the smallest was $2.7 \mathrm{~mm}$ in the treatment of 20 Gy. Gamma ray irradiation resulted in a decrease of around $27.1 \%$ in the treatment of $20 \mathrm{~Gy}$, whereas in the treatment of $10 \mathrm{~Gy}$ and $15 \mathrm{~Gy}$ the stem diameter decreased by about $10 \%$ and $24.4 \%$. The treatment of $15 \mathrm{~Gy}$ and $20 \mathrm{~Gy}$ was not significantly different, this could be caused by irradiation doses that would be received by plants not in accordance with the character of the plant. The smaller stem diameter showed that irradiation caused indirect growth of plants causing the stem diameter to be smaller. This was in line with the research of Mudibu et al. (2012) that soybeans irradiated with gamma rays showed changes in stem diameter because gamma irradiation produced free radicals that damaged and affected plant morphology.

Table 1. The average value of plant height, number of leaves, leaf length, leaf width, stem diameter, flower diameter and number of flowers in various doses of gamma irradiation at 12 weeks after planting

\begin{tabular}{lcccc}
\hline Character & Control $(\mathbf{0 ~ G y})$ & $\mathbf{1 0 ~ G y}$ & $\mathbf{1 5}$ Gy & $\mathbf{2 0 ~ G y}$ \\
\hline Plant height $(\mathrm{cm})$ & $52.7 \pm 3.9 \mathrm{a}$ & $35 \pm 3.9 \mathrm{~b}$ & $29.2 \pm 3.9 \mathrm{c}$ & $17.6 \pm 3.9 \mathrm{~d}$ \\
Number of leaves & $31 \pm 11.9 \mathrm{a}$ & $30.2 \pm 11.7 \mathrm{a}$ & $29.4 \pm 11.7 \mathrm{a}$ & $29.9 \mathrm{a} \pm 10.8 \mathrm{a}$ \\
Leaf Length $(\mathrm{cm})$ & $4.9 \pm 0.5 \mathrm{a}$ & $3.4 \pm 0.6 \mathrm{~b}$ & $2.7 \pm 0.3 \mathrm{c}$ & $2 \pm 0.3 \mathrm{c}$ \\
Leaf width $(\mathrm{cm})$ & $3.4 \pm 0.3 \mathrm{a}$ & $2.9 \pm 0.3 \mathrm{~b}$ & $2.2 \pm 0.3 \mathrm{c}$ & $1.3 \pm 0.2 \mathrm{~d}$ \\
Stem diameter $(\mathrm{mm})$ & $3.7 \pm 0.1 \mathrm{a}$ & $3.3 \pm 0.1 \mathrm{~b}$ & $2.8 \pm 0.1 \mathrm{c}$ & $2.7 \pm 0.1 \mathrm{c}$ \\
Flower diameter $(\mathrm{mm})$ & $3.3 \pm 0.4 \mathrm{a}$ & $3.5 \pm 0.4 \mathrm{a}$ & $2.8 \pm 0.3 \mathrm{~b}$ & $2.7 \pm 0.2 \mathrm{~b}$ \\
Number of flowers & $18.8 \pm 7.2 \mathrm{a}$ & $15.7 \pm 7 \mathrm{a}$ & $12.9 \pm 5.9 \mathrm{a}$ & $11.4 \pm 5.4 \mathrm{a}$ \\
\hline
\end{tabular}

Note: The number followed by the same letter shows not significantly different based on the DMRT test at the level of $5 \%$ 


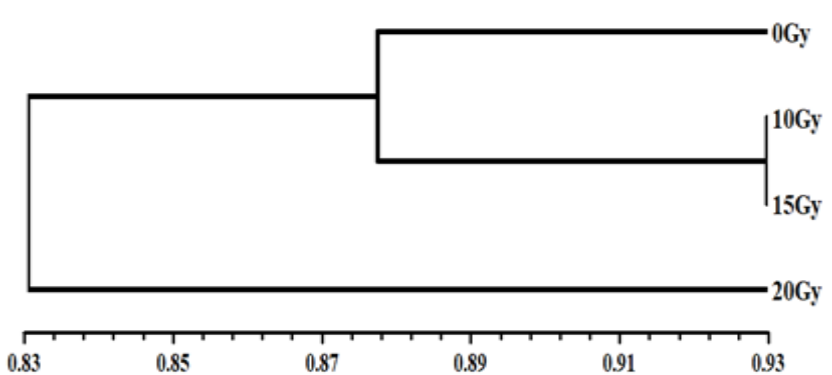

Figure 3. Dendrogram of plants based on morphology

Gamma ray irradiation had no significant effects on the number of Chrysanthemum flowers produced, with the highest average found in the control treatment and decreasing with increasing doses of gamma irradiation. While the average diameter of the largest flower on the control treatment was $3.3 \mathrm{~mm}$ and the smallest at the treatment of $20 \mathrm{~Gy}$ was $2.7 \mathrm{~mm}$. Decrease in diameter and number of flowers occurred because of the high irradiation dose given; the higher the dose given, the tissue cells would experience growth inhibition changes in plants caused by damage to cells due to the radiation dose given. Sutapa and Kasmawan (2016) stated that giving too high doses would inhibit cell division which caused cell death and affected the process of plant growth, decreased growth power and changes in plant morphology.

Changes in the diameter and amount of flowers due to irradiation occurred according to Boertjes and Van Harten (1998) because mutations can occur in somatic cells and can be expressed if an apical cell is introduced and will form a stable sector. Mutation expression is determined by the position of the exit of the flower, so that changes will be seen in the flowers that are formed from mutated tissue (Hartmann et al. 2011).

Dendrogram in Figure 3 showed that the treatment of 20 Gy had the farthest kinship with the control treatment, i.e. separate coefficients of around $10 \%$ and about $5 \%$ with the treatments of $10 \mathrm{~Gy}$ and $15 \mathrm{~Gy}$.

Induction of gamma irradiation caused increasing of diversity. Gamma rays as mutagens produced ions and free radicals in the form of hydroxyl $(\mathrm{OH})$. If the hydroxyl radical attached to the nucleotide chain in DNA, then a single thread of DNA would break and undergo changes in the genome (Mohr and Schopfer, 1995).

The increase in the morphological diversity of Chrysanthemums resulting from gamma irradiation increased significantly $(10 \%)$ occurred only in the treatment of $20 \mathrm{~Gy}$ when compared with the control. The results of this study indicated that gamma ray irradiation might be an adequate tool to increase plant diversity in Chrysanthemums. The results of this study were in line with the research of Mudibu et al. (2012) which showed an increase in the diversity of soybeans produced by irradiation at a dose of $20 \mathrm{~Gy}$.

Grouping analysis on plants produced by gamma irradiation did not show special grouping between control plants and plants produced by gamma irradiation where the treatment of $10 \mathrm{~Gy}$ and 15 Gy were grouped together with the control group with $100 \%$ similarity value. According to Medina et al. (2004), this occurred because the nature of mutations caused by gamma irradiation is individual, and parts of cells affected by irradiation experience different mutations between treatments.

The results of the dendrogram showed that the administration of gamma rays with treatment of $20 \mathrm{~Gy}$ had a long distance with the other treatments. Therefore a 20 Gy treatment can be used for plant breeding purposes because it produced high diversity. The lowest distance between the treatment of $10 \mathrm{~Gy}$ and 15 Gy showed that the plants of these groups had a close relationship so that they were less suitable for hybridization programs. Plants from the most different clusters can be selected to take into account the desired character.

In conclusion, gamma ray irradiation caused changes in the morphology of leaves and flowers, and affected the growth of Chrysanthemum plants. The treatment of $20 \mathrm{~Gy}$ produced a new leaf shape which was elongated. Stunted plant growth, changes in leaf texture and flower color were produced by gamma radiation with the treatments of $10 \mathrm{~Gy}$ and $20 \mathrm{~Gy}$. The dendrogram showed that the treatment of 20 Gy produced a higher diversity because the kinship is far away with the control treatment, $10 \mathrm{~Gy}$ and $15 \mathrm{~Gy}$.

\section{REFERENCES}

Banerji BK, Datta SK. 2002. Induction and analysis of gamma rays induced flower head shape mutation in 'Lalima' Chrysanthemum (Chrysanthemum molifolium). Indian J Agric Sci 72 (1): 6-10

Boertjes C, Harten AMV. 1998. Applied Mutation Breeding for Vegetatively Propagated Crops. Elvesier, Amsterdam.

Datta SK. 2001. Mutation Studies On Garden Chrysanthemum: A review. Sci Hort 7: 159-209.

Ferreira JJ, Garcia GC, Tous J, Rovira M. 2010. Genetic diversity revealed by morphological traits and ISSR markers in hazelnut germplasm from northern Spain. J Plant Breed 129: 435-441

Hartmann HT, Kester DE, Davies FT, Geneve RL. 2011. Hartman and Kester Plant Propagation: Principles and Practices. 8th ed. Prentice Hall, Boston.

Herison C, Rustikawati SH, Sutjahjo, Aisyah SI. 2008. Induksi mutasi melalui iradiasi sinar gamma terhadap benih untuk meningkatkan keragaman populaso jagung (Zea mays L). J Akta Agrosia 11 (1): 57 62. [Indonesian]

Lukanda LT, Mbuyi KKC, Nkongolo RV, Kizungu. 2013. Effect of gamma irradiation on morpho-agronomic acharacteristic of groundnut (Arachis hypogaea L.). Amer J Plant Sci 4: 2186-2192

Medina F, Amano E, dan Tano S. 2004. Mutation breeding Manual. Forum for Nuclear Cooperation in Asia (FNCA), Japan.

Mohr H, Schopfer. 1995. Plant Physiology. Springer-Verlag, Berlin

Mudibu J, Nkongolo KKC, Mehes-Smith M, Kalonji-Mbuyi A. 2012 Genetic analysis of soybean genetic pool using ISSR marker: effect gamma radiation on genetic variability. Intl J Plant Breed Genet 5 (3): 235-245.

Muthusamy A, Vasanth K, Sivasankari D, Chandrasekar BR, Jayabalan N. 2007. Effect of Mutagens on Somatic Embryogenesis and Plant Regeneration in Groundnut. Boil. Plant 51: 430-435.

Ramesh HL, Murthy VNY, Munirajappa. 2014. Induction of useful mutation in mulberry (Morus) variety s54 by gamma irradiation in M1 generation. Amer J Exp Agric 4: 48-57.

Rohlf FJ. 2000. NTSYSpc: Numerical Taxonomy And Multivariate Analysis System, Version 2.1. Exeter Software, NY

Rosmala A, Nurul K, Dewi S. 2015. Perubahan morfologi dan pertumbuhan Handeuleum (Graptopnyllum pictum L. Griff) akibat 
iradiasi sinar gamma. J Agron Indonesia 43 (3): 235-241. [Indonesian]

Srivastava P, Kumar G. 2011. Gamma rays induced alterations in some morphological and biochemical indices of safflower (Carthamus tinctorius L.). J Plant Sci Res 27: 113-116.

Sutapa GN, Kasmawan IGA. 2016. Efek induksi mutasi radiasi gamma 60Co pada pertumbuhan fisiologi tanaman tomat (Lycopersicon esculentum L). J. Keselamatan Radiasi dan Lingkungan 1 (2): 5-11. [Indonesian]

Tantasawat P, Trongchuen J, Prajongjai T, Seehalak W, Jittayasothorn Y. 2010. Variety identification and comparative analysis of genetic diversity in yardlong bean (Vigna unguiculata spp. sesquipedalis) using morphological characters, SSR and ISSR analysis. J Sci Hortic 124: 204-216.
Van Harten, AM. 1998. Mutation Breeding: Theory and Practical Application. Cambridge University Press. United Kingdom

Yadav S, Rana P, Saini N, Jain S, Jain RK. 2008. Assessment of genetic diversity among rice genotypes with differential adaptations to salinity using physio-morphological and molecular markers. J Pl Biochem Biotechnol 17 (1): 1-8.

Wi SG, Chung BY, Kim JS, Kim JH, Baek MH, Lee JW, Kim YS. 2007. Effect of gamma irradiation on morphological changes and biological responses in plant. Micron 38: 553-564.

Widiastuti A, Sobir MR, Suhartanto. 2010. Diversity analysis of mangosteen (Garcinia mangostana) irradiated by gamma ray based on morphological and anatomical characteristic. Nusantara Biosci 2: 23-33. 